\title{
Presentation of the Dossier
}

The eight texts in the dossier Religion, Material Culture and Visual Culture together prove the relevance of the theme for different areas of religious studies and theological studies: textual studies, including founding, ecclesiastical, doctrinal and historical texts; material studies, both archaeological and architectural, including public spaces; ritualistic studies, of bodies in movement and in multiple relationships, with people, with oneself, God, spaces and artifacts; and, last not least, visual studies, including logos, ornaments, religious, liturgical and religious arts, symbols and virtual spaces. All of this takes place in a descriptive, analytical way or deepens in its epistemological foundation, often still, in an interdisciplinary way, adding, not infrequently, to the research on religion established and considered consecrated new perspectives, representing new challenges.

The first texts focus on contexts of Old Testament texts. In "The God's aesthetics: material exchanges in the theological construction of the idea of divinity in ancient Israel", explores Dr. João Batista Ribeiro Santos, professor at the School of Theology at Umesp and recently completed a post-doc in Ancient History at the Faculty of Sciences and Letters of the Universidade Estadual Paulista (Unesp), alongside the biblical texts, the historical relationship between space and the imagined presence of the divinity from the ritualistic art of the sacred spaces and what it tells us about conceptual and political conflicts of the time.

From the same research period, Dr. Silas Klein Cardoso is currently a postdoctoral fellow at the University of Bern, Switzerland. He familiarizes us with the challenges that material studies, in this case, archaeological ones, can represent for our understanding of the founding texts: "The Temples of the House of Saul? Dissonances between the biblical and material records".

Vinícius Couto, a doctoral student at Umesp, shares with us an aspect of his ongoing doctoral research. In "Between truth and heresy: iconographic representations of Jacobus Arminius as a hero reformer and disturber of religion", he recalls that theological disputes often occur through multiple means, including images. It is not a small charm that for that the contractors needed to learn to use a third language, the visual language. How this was 
done in the 17th century among Calvinists is the subject of your text.

Dr. Helmut Renders, professor at Umesp School of Theology and PPG in Sciences of Religion, presents a text within his main effort to present the evangelical visual culture. This time, he focuses on devotional works from the turn of the 17th to the 18th century and recalls the memory of the use of almost 500 images in two works by Anglican priest Samuel Wesley. "The religious visual language in works of Samuel Wesley: a short introduction into his choice of artists and some iconographic aspects" shows how the Anglican was used to the use of visual culture, the way in which he chooses the best artists with national fame for to produce the engravings of his books and that one of the functions of these images is to "vitalize" the relationship of [the] reader with the biblical text.

Following is a text written in two hands. Lídia Kameyo Ueda-Fischer, currently a master's student at the PPG in Sciences of Religion, and Helmut Renders, present a research, initially developed by her under her guidance. "The visual language of Foster's Family Pictorial Bible from 1890, and its articulation of religious affection and social sensitivity" catapults us to a text brought from the United States of America to Brazil, probably by Methodist missionaries. This genre of Family Pictorial Bibles is an original American product, opened by the Methodist Harper in 1848. The authors establish a relationship between the images, their creator and their message as means of projecting and promoting a dynamic social religious project.

Dr. David Morgan from Duke University in Durnham, NY/USA, from the Departments of Religious Studies, Art and Art History and Visual Studies, currently one of the leading experts in the field and co-founder of the renowned scientific journal Material Religion, contextualizes this genre of Bibles in a bigger picture while, introducing its reader to the "... visual culture of American Protestantism in the 19th century". The text is kept in English and is published here with the permission of the State University of Pará/Brazil in the person of the coordinator of its Graduate Program in Sciences of Religion, Dr. Douglas Rodrigues da Conceição, since the Portuguese version will be published soon in a collaborative publication between this program and the Postgraduate Program in Religious Sciences at Umesp. We thank you for the opportunity and hope to reach, in this way, a different audience.

The next article was also written by two people. Dr. Vitor Chaves de Souza, professor of the Postgraduate Program in Religious Sciences at Umesp, and Ana Beatriz de Carvalho dos Santos Alexandrini, master of the program and even a researcher on the aforementioned Harper's Family Pictorial Bible, explore in "Imaginary variations and religious symbolism: Hermeneutical 
approaches" the survival of primordial images in the subconscious as well as the archaic values preserved in the cultural and founding symbols of the societies that constitute the imaginary of a given culture.

Finally, it takes us to Dr. Márcio Luiz Fernandes, professor of the Postgraduate Program in Theology at the Pontifical Catholic University of Paraná, for a past that is still present. In "The mural art of Mino Cerezo Barredo in the Brazilian military period" examines some of the works carried out by the artist during the military period and explores their respective relationships, whether with the context of sacred art of the 20th century in Latin Ameri$\mathrm{ca}$, or with the denunciation of horrors and violence practiced against the most vulnerable groups of Brazilian society in that period, remembering the humanizing and humanizing role of art in its liberating dimension.

We are grateful for the contributions that once again bought the important part of this research field with an indication of the launch of the first book in our area of Sciences of Religion and Theology fully dedicated to the studies of visual and material culture, even in that year 2020: HIGUET, Etienne Alfred; MENDONÇA, Katia; RENDERS, Helmut (orgs.). Material and visual culture as languages of religion. UEPA publisher, [2020].

On behalf of the organizers of this dossier,

Prof. Dr. Frederico Pieper (UFJF)

Prof. Dr. Luis Américo Silva Bonfim (UFS)

Prof. Dr. Helmut Renders (UMESP)

Translation of João Batista Ribeiro Santos 